\title{
Transmission of Phytophthora infestans from Infected Potato Seed Tubers to Emerged Shoots
}

\author{
Dennis A. Johnson, Department of Plant Pathology, Washington State University, Pullman 99164-6430
}

\begin{abstract}
Johnson, D. A. 2010. Transmission of Phytophthora infestans from infected potato seed tubers to emerged shoots. Plant Dis. 94:18-23.

Transmission of Phytophthora infestans from infected seed tubers to emerged potato sprouts, infectivity of sporangia deposited on whole tubers before burial in soil, and infectivity of sporangia in a loamy fine sand to leaflets were investigated in the greenhouse under simulated spring planting conditions of the Columbia Basin. Incidence of late-blight-infected shoots from infected seed tubers was significantly greater when foliage was exposed to wet periods in mist chambers (mist for $45 \mathrm{~s}$ every $15 \mathrm{~min}$ ) for either 24 or $48 \mathrm{~h}$ than when not exposed to a wet period. Proportion of infected shoots from infected tubers was 0.210 to 0.261 in a moist environment versus 0.013 to 0.052 in a nonmist environment. Development of chlorosis, necrosis, and sporangia occurred on shoots that emerged from infected, symptomatic tubers buried in soil. However, approximately $20 \%$ of the infected shoots produced sporangia before stems had visible discoloration of late-blight symptoms. Sporulation was sparse and formed near the soil line on some of the shoots after $24 \mathrm{~h}$ in the moist environment. The latent period or time from inoculation to sporulation on young stems of Russet Burbank was 5 to 6 days, which is too long to account for an infection from either sporangia or zoospores at the soil level of shoots during the wet period in this study. Sporangia were infective when placed directly on eyes of whole tubers before planting. Leaflets touching a loamy fine sand infested with sporangia developed typical late-blight lesions beginning at the leaflet tip within 7 days after a 24-h wet period and the infested loamy fine sand was infective when splashed on leaflets.
\end{abstract}

Phytophthora infestans (Mont.) de Bary, the cause of potato late blight, survives in infected tubers which may act as an inoculum source the following season $(26,38)$. In the Pacific Northwest of North America, oospores of $P$. infestans are not currently known to be a factor in overwintering, and a continuum of viable host tissue is essential for overwintering and transmission of $P$. infestans to new plant tissues $(26,38,39)$. Infected tubers are considered to be the main means of overwintering for the pathogen. Infected tubers serving as overwintering and primary inoculum sources may be (i) potato seed tubers $(9,19)$, (ii) potato tubers left in the field after harvest that produce volunteer plants $(12,39)$, and (iii) cull potato tubers $(6,21,39)$. Infected potato seed tubers, cull piles, and volunteer potato plants have all been important primary source of inoculum in the Columbia Basin of Washington and Oregon (17;

Corresponding author: D. A. Johnson

E-mail: dajohn@wsu.edu

PPNS no. 0500, Department of Plant Pathology, College of Agricultural, Human, and Natural Resource Sciences Agricultural Research Center, Project No. WNPO 0678, Washington State University, Pullman 99164-6430.

Accepted for publication 23 September 2009.

doi:10.1094/PDIS-94-1-0018

(C) 2010 The American Phytopathological Society unpublished). Latently infected tubers have been implied from an epidemiological study in the Ecuadorian highlands (23) and demonstrated by detecting the pathogen in asymptomatic tubers with the polymerase chain reaction (PCR; 1,2,15) and by inducing symptom development and sporulation on potato seed tubers after long-term cold storage (18). The relative importance of the three types of late-blight-infected tubers likely varies and depends, in part, on microclimates, local conditions, and the extent of infection the previous fall $(9,12,39)$.

Transmission of $P$. infestans from infected tubers to plant tissues of the next season's crop may occur during seed-tuber handling, cutting, and planting (25) or in the field $(14,26)$. The potential for one or more cycles of infection has been demonstrated when seed tubers are handled and cut (25). For secondary infection to occur during cutting and handling, the pathogen must survive in intact tubers during the winter, sporulate, be dispersed, and infect additional tubers or plants. $P$. infestans produces sporangia on tubers $(11,12,25,29)$, and sporulation has occurred within $19 \mathrm{~h}$ after seed tubers with late-blight symptoms were removed from cold storage to a warmer environment at high humidity (32). Sporangia were readily transmitted by direct contact from infected tubers or seed pieces to noninfected seed pieces (11). Infection during seed-tuber cutting and handling likely increases the threat of late-blight outbreaks on foliage in the field (25). Fungicide seed piece treatments potentially reduce transmission on seed tubers $(16,34)$.

The exact pathway by which $P$. infestans progresses from planted, infected seed tubers to the new plant is not clear and is disputed $(3,7,26)$. P. infestans is thought to spread by mycelial growth within infected seed tubers, advancing contiguously or following growing shoots to produce sporangia capable of generating new infection foci $(10,26,38)$. This pathway was recently confirmed when $P$. infestans was detected in asymptomatic shoots emerging from infected tubers with the aid of the PCR $(1,2,4,15)$. Latent infections in tubers and emerging shoots pose additional challenges in managing late blight.

Emergence of infected shoots from infected seed pieces is often low, and infected seed tubers frequently result in a reduced stand due to tuber rot and preemergence blighting of shoots $(7,14,26)$. For example, over five consecutive years, only 21 of $3,260(0.64 \%)$ infected seed tubers planted produced infected aboveground shoots capable of sporulating (14). In experiments in Oregon and Washington (27), transmission from artificially infected seed pieces to emerging shoots was 1.9 to $3.8 \%$ of the inoculated seed piece, depending on the cultivar. In a recent study, tuberto-sprout transmission was as high as $25 \%$ on plants held at 60 to $90 \%$ relative humidity in the greenhouse. Transmission was greater with a US-8 than US-11 isolate (12). Temperature and moisture have not been directly associated with transmission of $P$. infestans from tubers to shoots $(7,14)$; however, rainy and cloudy weather may have favored the extension of $P$. infestans from infected seed-tubers to aboveground shoots during 2 years in a field study (14). In preliminary experiments in my laboratory, infected shoots arising from infected seed tubers were more numerous when incubated in a mist chamber than when kept outside of a moist environment. Environmental conditions that may promote development of infected shoots from the infected seed tubers have not been identified. Understanding factors that promote pathogen transmission from seed tubers to shoots is a major goal in developing management strategies for the disease.

The transmission rate from infected seed tuber to foliage does not need to be very high for a late-blight epidemic to develop, given the explosive polycyclic capabilities 
of $P$. infestans and the large amount of potato seed planted in a major production region like the Columbia Basin $(14,26$, 37,38). For example, the number of seed pieces planted in the Columbia Basin in 2007 was over $2.625 \times 10^{9}$, with the total weight of seed pieces being 156,300 metric tons. The number of seed potato pieces cut was over $8.7 \times 10^{8}$, assuming a mean seed piece weight of $60 \mathrm{~g}$, a mean seed tuber size of $170 \mathrm{~g}$, and 5\% wastage. Calculations were based on 65,650 ha harvested in the Columbia Basin of Washington and Oregon; approximately 39,970 potato seed pieces planted per hectare when using standard within-row and between-row spacings of 29 and $86 \mathrm{~cm}$, respectively (35); and accounting for planting inefficiencies such as skips and doubles (28). Because of the extremely large ratio of seed tubers planted to those capable of inducing an outbreak, a greater understanding is needed of the transmission of $P$. infestans from potato seed tubers to the succeeding crop.

Sporangia produced on potato seed tubers during cutting, handling, and planting could potentially be dispersed and deposited on noninfected tubers and field soil (23). Transmission of $P$. infestans from infested soil to leaves was demonstrated by Boyd (7); however, infectivity of soils from the Columbia Basin to foliage is not known. In addition, infectivity of sporangia deposited on tuber eyes before planting is not known.

The primary purpose of this research was to investigate the effect of a mist period on the expression of late-blight symptoms on shoots emerging from infected seed tubers. The hypothesis is that air moisture following asymptomatic shoot emergence promotes symptom expression and transmission of the pathogen from the tuber. The study was done in a greenhouse under simulated potato-growing conditions representing spring soil temperatures and moisture of the semiarid environment of the Columbia Basin. Secondary objectives were to investigate the infectivity of sporangia deposited directly on tubers before planting, and the infectivity of sporangia in a loamy fine sand to leaflets.

\section{MATERIALS AND METHODS}

A US-8 isolate of the A2 mating type (BF05) of $P$. infestans was used in these studies. The isolate was obtained from potato foliage collected in northern Idaho in 2005 , maintained at $4.2^{\circ} \mathrm{C}$ in potato tubers of cv. Russet Burbank during winter months of October through March, and transferred to excised leaflets of cv. Russet Burbank during the remainder of the year as previously described (31). Inoculum was increased on inoculated leaflets placed on a nylon mesh screen over moistened paper towels in a glass tray (humidity chamber), sealed in a polyethylene bag, and incubated at $15^{\circ} \mathrm{C}$ for 7 days (31).
Certified seed tubers of cv. Russet Burbank used in this study were produced near Ronan, Montana, where late blight was not known to be present, and were assumed to be free of the pathogen. Tubers were stored at approximately $4^{\circ} \mathrm{C}$ and warmed to $15^{\circ} \mathrm{C}$ before inoculation.

Tubers were inoculated with $P$. infestans using one of two methods. With the first inoculation method, the concentration of sporangia in a water suspension was adjusted to 10,000 sporangia/ml of distilled water using a hemacytometer. Sporangia were then chilled for $2 \mathrm{~h}$ at $4^{\circ} \mathrm{C}$ to induce zoospore formation. Inoculation was done by applying $0.05 \mathrm{ml}$ of inoculum with a micropipette to a Whatman no. 2 filter paper cut into 10-by-10-mm squares and then placing the saturated filter paper square onto a single eye on a tuber or onto an excised leaflet. Inoculated tubers were then placed in a mist chamber for $20 \mathrm{~h}$ at 16 to $20^{\circ} \mathrm{C}$ and allowed to air dry for $1 \mathrm{~h}$. A filter paper square saturated in distilled water was placed over a single eye of tubers used for the noninoculated control.

The second inoculation method was done to determine the infectivity of sporangia placed directly on tubers before planting. Inoculum was produced on excised leaflets of Russet Burbank as described previously. Inoculations were done by applying sporangia directly onto tuber tissue by gently tapping the leaflet containing sporangia on a certified seed tuber of Russet Burbank. The leaflets used for inoculation did not have visible, condensed moisture. Tubers that did not receive sporangia from an excised leaflet were used as noninoculated controls. Inoculated and control tubers were placed in a greenhouse potting mix (LC1 Soil Mix; Sun Gro Horticulture, Canada Ltd.).

Experiments in the greenhouse were done in the spring and summer months and artificial lights were not used. Tempera- tures in the greenhouse were 20 to $24^{\circ} \mathrm{C}$ during the day and 10 to $19^{\circ} \mathrm{C}$ during the night. Relative humidity ranged from 20 to $45 \%$.

Transmission from infected seed pieces to shoots. Emerged shoots from infected tubers were used to investigate the role of a mist period on the expression of late-blight symptoms on shoots. Infected tubers were produced by inoculating certified seed tubers. Seed tubers were inoculated at a single eye near the stem end of tubers using the filter paper method and placed in a mist chamber as previously described. Tubers were then planted in a potting mix in 3-liter pots, covered with approximately $4 \mathrm{~cm}$ of the potting mix, and placed on a greenhouse bench. When shoots had emerged and grown to approximately 3 to $14 \mathrm{~cm}$ in height, randomly selected pots with shoots were placed in a mist chamber for $24 \mathrm{~h}$ at 17 to $20^{\circ} \mathrm{C}$. Shoots were examined for sporangia and blighting after each 24-h wet period.

In a set of seven trials in 2007, 4 to 17 pots with emerged shoots were either placed in the mist chamber (mist for $45 \mathrm{~s}$ every $15 \mathrm{~min}$ ) for $24 \mathrm{~h}$ or left in the greenhouse (Table 1). In a second set of six trials in 2007, 12 to 17 pots with emerged shoots were placed either in the mist chamber for $48 \mathrm{~h}$ or left in the greenhouse (Table 2). In a set of three trials in 2008, 3 to 5 pots with emerged shoots were either placed in a mist chamber for $24 \mathrm{~h}$ or left in the greenhouse (Table 1). Shoots were individually examined for sporangia with a $\times 10$ power hand lens and late-blight symptoms immediately after each wet period. Each of the 16 trials was done on a separate day.

Pots with shoots were then returned to the greenhouse bench and again assessed for late-blight symptoms $24 \mathrm{~h}$ after the termination of the 24 - or 48 -h wet periods. Control shoots that had not been subjected

Table 1. Incidence of infected and symptomatic tubers and shoots when healthy-appearing shoots from Russet Burbank seed tubers inoculated with Phytophthora infestans were placed or not placed in a mist chamber ( $45 \mathrm{~s}$ of mist every $15 \mathrm{~min}$ ) for $24 \mathrm{~h}$ in seven trials in 2007 and three trials in 2008

\begin{tabular}{|c|c|c|c|c|c|c|}
\hline \multirow[b]{2}{*}{ Year, trial } & \multicolumn{2}{|c|}{$\begin{array}{l}\text { Incidence of infected } \\
\text { tubers with symptomatic } \\
\text { shoots }(\%)\end{array}$} & \multicolumn{2}{|c|}{$\begin{array}{c}\text { Proportion of } \\
\text { symptomatic shoots }^{\mathrm{a}}\end{array}$} & \multicolumn{2}{|c|}{$\begin{array}{l}\text { Total no. of } \\
\text { infected tubers }\end{array}$} \\
\hline & Mist & No mist & Mist & No mist & Mist & No mist \\
\hline \multicolumn{7}{|l|}{2007} \\
\hline 1 & 27 & 0 & 0.36 & 0 & 11 & 4 \\
\hline 2 & 18 & 0 & 0.18 & 0 & 17 & 12 \\
\hline 3 & 17 & 0 & 0.17 & 0 & 12 & 17 \\
\hline 4 & 13 & 8 & 0.13 & 0.08 & 16 & 13 \\
\hline 5 & 10 & 0 & 0.20 & 0 & 10 & 11 \\
\hline 6 & 27 & 0 & 0.27 & 0 & 11 & 10 \\
\hline 7 & 55 & 0 & 0.64 & 0 & 11 & 10 \\
\hline Mean $^{\mathrm{b}}$ & $23.9 * *$ & 1.1 & $0.27 *$ & 0.01 & 12.6 & 9.3 \\
\hline \multicolumn{7}{|l|}{2008} \\
\hline 1 & 20 & 0 & 0.20 & 0 & 5 & 5 \\
\hline 2 & 40 & 0 & 0.40 & 0 & 5 & 5 \\
\hline 3 & 33 & 0 & 0.67 & 0 & 3 & 3 \\
\hline Mean $^{b}$ & $31.1 * *$ & 0 & $0.42 * *$ & 0 & 4.3 & 4.3 \\
\hline
\end{tabular}

a Number of shoots with symptoms per total infected tubers.

${ }^{\mathrm{b}}$ For difference between mist and no mist, $*$ and $* *$ indicate $P=0.002$ and 0.008 , respectively. 
to the wet period were also assessed for late-blight symptoms and sporangia. In four trials in 2007, some shoots did not have symptoms immediately after the wet periods but had late-blight symptoms $24 \mathrm{~h}$ after the termination of the wet period (Table 3). These four trials were combined for a fourth set of trials for data analysis.

The potting mix around the belowground segment of eight symptomatic shoots from three trials was gently extracted and the shoot was removed from the seed tuber. The stem tissue from the seed tuber upward was then examined for external discoloration.

Infectivity of sporangia deposited on tubers before planting. Tubers were inoculated before planting to determine infectivity of sporangia deposited directly on tubers before planting. Sporangia were applied to 20 whole tubers by tapping a leaflet containing sporangia on tubers. Five tubers were not inoculated and were used as controls. Tubers were planted (1 tuber/pot) in the potting mix in 3-liter pots $(15 \mathrm{~cm}$ in diameter) and placed on a greenhouse bench for 3 weeks. Depth of potting mix over the top of the tuber was 4 $\mathrm{cm}$. Moisture content of the potting mix was $50 \%$, as determined by weighing samples before and after drying in an oven. Distilled water was first applied to each of five pots at planting, 7 days after planting, 14 days after planting, or not applied. Distilled water was applied at planting to the noninoculated controls. Tubers were assessed for infection 6 weeks after inoculation. The trial was repeated.

Infectivity of infested soil. A Quincy loamy fine sand from sagebrush land adjacent to a potato field east of Paterson, WA was used to determine infectivity of infested soil because it was assumed to be free of $P$. infestans. Sporangia were produced on excised leaflets, washed from leaflets, adjusted to 10,000 sporangia/ml of distilled water and then chilled for $2 \mathrm{~h}$ at $4^{\circ} \mathrm{C}$. Approximately $50 \mathrm{ml}$ of the sporangium suspension was added to $150 \mathrm{~cm}^{3}$ of the soil. The infested soil was placed on top of noninfested fine loamy sand contained in two 15 -cm-diameter, 3-liter pots that were nearly filled to capacity. The depth of the infected soil was approximately $4 \mathrm{~mm}$. The pots with infested soil were placed in a mist chamber with a leaflet tip from an adjacent, noninfected, potted Russet Burbank plant touching the infested soil. One leaflet tip was touching infested soil in each of the two pots. A small aggregate of infested loamy fine sand about $0.5 \mathrm{~mm}^{3}$ in volume was placed on the center of a leaflet on a separate leaf to simulate sand that had splashed on to the leaflet. The plants were left in the mist chamber for $24 \mathrm{~h}$ at 18 to $21^{\circ} \mathrm{C}$, then placed on a greenhouse bench at 13 to $23^{\circ} \mathrm{C}$ for 9 days. Plants that developed lesions were placed again in the mist chamber for $24 \mathrm{~h}$ at 18 to $21^{\circ} \mathrm{C}$ to induce

Table 2. Incidence of infected and symptomatic tuber and shoots when healthy-appearing shoots from Russet Burbank seed tubers inoculated with Phytophthora infestans were placed or not placed in a mist period ( $45 \mathrm{~s}$ of mist every $15 \mathrm{~min}$ ) for $48 \mathrm{~h}$ in six trials in 2007

\begin{tabular}{|c|c|c|c|c|c|c|}
\hline \multirow[b]{2}{*}{ Trial } & \multicolumn{2}{|c|}{$\begin{array}{l}\text { Incidence }(\%) \text { of } \\
\text { infected tubers with } \\
\text { symptomatic shoots }\end{array}$} & \multicolumn{2}{|c|}{$\begin{array}{c}\text { Proportion of } \\
\text { symptomatic shoots }^{\mathrm{a}}\end{array}$} & \multicolumn{2}{|c|}{ Total no. of infected tubers } \\
\hline & Mist & No mist & Mist & No mist & Mist & No mist \\
\hline 1 & 6 & 8 & 0.12 & 0.08 & 17 & 12 \\
\hline 2 & 0 & 0 & 0 & 0 & 10 & 10 \\
\hline 3 & 50 & 15 & 0.63 & 0.23 & 16 & 13 \\
\hline 4 & 7 & 0 & 0.07 & 0 & 15 & 14 \\
\hline 5 & 8 & 0 & 0.17 & 0 & 12 & 14 \\
\hline 6 & 17 & 0 & 0.17 & 0 & 12 & 14 \\
\hline Mean $^{\mathrm{b}}$ & $14.7 *$ & 3.8 & $0.19 * *$ & 0.052 & 13.7 & 12.8 \\
\hline
\end{tabular}

${ }^{a}$ Number of shoots with symptoms per total infected tubers.

${ }^{\mathrm{b}}$ For difference between mist and no mist, ${ }^{*}$ and $* *$ indicate $P=0.042$ and 0.020 , respectively.

Table 3. Incidence of infected tubers and symptomatic tubers and shoots when healthy-appearing shoots from Russet Burbank seed tubers inoculated with Phytophthora infestans were placed or not placed in a mist chamber ( $45 \mathrm{~s}$ of mist every $15 \mathrm{~min}$ ) for $48 \mathrm{~h}$ and then placed on a greenhouse bench for $24 \mathrm{~h}$ in four trials

\begin{tabular}{|c|c|c|c|c|c|c|}
\hline \multirow[b]{2}{*}{ Trial } & \multicolumn{2}{|c|}{$\begin{array}{l}\text { Incidence }(\%) \text { of } \\
\text { infected tubers with } \\
\text { symptomatic shoots }\end{array}$} & \multicolumn{2}{|c|}{$\begin{array}{c}\text { Proportion of } \\
\text { symptomatic shoots }^{\mathrm{a}}\end{array}$} & \multicolumn{2}{|c|}{ Total no. of infected tubers } \\
\hline & Mist & No mist & Mist & No mist & Mist & No mist \\
\hline 1 & 55 & 0 & 0.91 & 0 & 11 & 4 \\
\hline 2 & 17 & 0 & 0.33 & 0 & 12 & 12 \\
\hline 3 & 9 & 0 & 0.18 & 0 & 11 & 10 \\
\hline 4 & 10 & 0 & 0.30 & 0 & 10 & 10 \\
\hline Mean ${ }^{b}$ & $22.8 *$ & 0 & $0.43 * *$ & 0 & 11 & 9 \\
\hline
\end{tabular}

a Number of shoots with symptoms per total infected tubers.

${ }^{\mathrm{b}}$ For difference between mist and no mist, * and ** indicate $P=0.032$ and 0.029 , respectively. sporulation from developed lesions. This experiment was conducted three times.

Data analysis. The incidence of infected tubers with symptomatic shoots and the proportion of symptomatic shoots per total number of infected tubers were used to determine the development of symptomatic shoots from infected tubers. Data for development of symptomatic shoots immediately after termination of the wet period were used for the first three sets of trials and data for development of symptomatic shoots $24 \mathrm{hr}$ after termination of the wet periods were used for the fourth set of trials. Data for each of the discrete trials were calculated separately within the four sets of trials. The individual trials were considered replications within each of the four set of trials or experiments. Data from the four sets of trials were analyzed separately because they were done at different times and not intended for comparison (Tables 1, 2, and 3). Each of the four sets of trials was analyzed as a two-way analysis of variance (ANOVA), where independent variables were the contiguous trials (replications) and the treatments were mist and nonmist periods. Data for incidence of infected tubers with symptomatic shoots and the proportion of symptomatic shoots per total infected tubers were analyzed using an arcsine square root transformation to best satisfy variance assumptions. PROC MIXED procedure (SAS Institute, Carey NC) was used to test for significance among trials and treatment effects for each of the four experiments. Comparison of treatment means was based on the least square means from the ANOVA model using PROC GLM in SAS (version 9.1; SAS Institute).

Data collected to investigate the infectivity of sporangia deposited on tubers before planting were analyzed with regression analysis using REG. Incidence of infected tubers (dependent variable) was considered to change over time of first watering (independent variable) if the regression coefficient (slope) was significantly greater than 0 at $P<0.05$. The treatment not receiving water was not included in the analysis because zero was not defined by number of days for first watering. The trials to investigate the infectivity of a loamy fine sand infested with sporangia on potato leaflets was observational and statistical tests were not done to test hypotheses. Koch's postulates were used to demonstrate infection.

\section{RESULTS}

Transmission from infected seed pieces to shoots. The incidence of infected tubers with symptomatic shoots was greater when foliage was exposed to a 24-h wet period than when not exposed in 2007 $(P=0.002)$ and $2008(P=0.001)$ (Table $1)$. The proportion of symptomatic shoots per infected tubers was greater when foliage was exposed to a 24 -h wet period than 
when not exposed in $2007(P=0.002)$ and $2008(P=0.008)$ (Table 1). The incidence of infected tubers with symptomatic shoots was greater when foliage was exposed to a 48-h wet period than when not exposed $(P$ $=0.042$ ) (Table 2). The proportion of symptomatic shoots per infected tubers was greater when foliage was exposed to a 48-h wet period than when not exposed ( $P$ $=0.020$ ) (Table 2). All of the symptomatic shoots from the mist chamber supported sporangia of $P$. infestans. In all, 9 of 40 $(22.5 \%)$ infected shoots in the mist environment produced sporangia before stems had visible discoloration. Sporulation was light and formed near the soil line on some infected shoots at $24 \mathrm{~h}$ (Fig. 1). Infected shoots were not produced from noninoculated control seed tubers.

Additional symptomatic shoots became evident within $24 \mathrm{~h}$ of removing plants from the mist chamber in four trials in 2007. The incidence of infected tubers with symptomatic shoots was greater when foliage was previously exposed to a wet period than when not exposed $(P=0.032$; Table 3 ). The proportion of symptomatic shoots per infected tubers was greater when foliage was previously exposed to a wet period than when not exposed $(P=$ 0.029; Table 3). The control plants not placed in the mist chamber did not exhibit symptomatic shoots in any of the trials.

Discolored stem tissue began about 1 $\mathrm{cm}$ or less below the soil line and continued up into the aboveground stem in the eight symptomatic shoots examined for belowground tissue discoloration. The remaining belowground tissue down to the seed piece remained asymptomatic in seven of the examined shoots. Reddishbrown streaking appeared on the belowground stem of the eighth shoot.

Infectivity of sporangia deposited on tubers before planting. Whole tubers became infected when sporangia were placed directly on eyes before planting. The percentage of infected tubers was 100 , 80,100 , and 60 when pots were first watered at time of planting, 7 days after planting, 14 days after planting, and not watered, respectively. When the trial was repeated, the percentage of infected tubers was $40,60,20$, and 0 when pots were first watered at time of planting, 7 days after planting, 14 days after planting, and not watered, respectively. Percentage of infection did not significantly change with time of first watering in first $(P=1.00)$ and second trials $(P=0.089)$. Typical lateblight symptoms developed in infected tubers, and sporangia of $P$. infestans later developed on tubers tissues placed in a humid chamber at $15^{\circ} \mathrm{C}$. The noninoculated control tubers did not become infected in either trial.

Infectivity of infested soil. All six leaflets touching infested soil during the three experiments developed typical late-blight lesions beginning at the leaflet tip within 7 days after the wet period. In addition, lateblight lesions developed in the leaflets where a small aggregate of infested loamy fine sand was placed within 7 days after observed 6 days after inoculation. Sporangia of $P$. infestans developed in and around the lesions when potted plants with the lesions were placed in a mist chamber for $24 \mathrm{~h}$ after the lesions had developed. Lateblight lesions did not develop on six leaflets used as noninoculated controls.

\section{DISCUSSION}

Mist periods promoted transmission of $P$. infestans from infected seed tubers to emerged shoots. Healthy-appearing shoots developed late-blight symptoms during a 24- to 48-h mist period or within a day after shoots were exposed to a wet period. Mean proportion of shoots expressing symptoms after emergence ranged from 21 to 42 per 100 infected tubers (Tables 2 and 3 ). Expression of symptomatic shoots has not been consistent in previous studies $(7,14,26)$, likely because the effect of moisture on blighted shoot expression was not fully recognized. This result may also explain why transmission rates from infected tubers to foliage are generally low under arid conditions (14).

De Bary was the first to summarize that "the vegetation" of $P$. infestans was "largely hastened and assisted by damp, and on the other hand, retarded by drought" (10). The validity of De Bary's work on vegetation of the pathogen was then questioned when not duplicated by other researchers, as described by Melhus (26). In addition to promoting expression of infected shoots, moisture favored production of sporangia on the emerged shoot. Sporangia were also sometimes produced the wet period. Initial lesions were usually

on shoots before lesions appeared. Wet periods at mild temperatures not only promote expression of blighted shoots from infected seed tubers but also favor repeated cycles of sporulation and infection on foliage in the field. Late blight is highly dependent on moisture for sporulation and infection, and results from this study imply that moisture also promotes initial epidemic development.

Determining the initial source of lateblight infection after overwintering is difficult once potato plants in a commercial field are infected (14). The dilemma has been previously summarized in that, by the time a group of infected plants is noticed in a field, it is usually too late to decide how the infection originated (8). This observation is more understandable since the present research determined that sporulation may precede late-blight symptoms of chlorosis and necrosis on shoots arising from infected seed pieces and also that initial sporulation may be sparse, making early detection extremely difficult. As a result, one or more secondary cycles of infection often occur before symptomatic plants are observed in commercial fields $(37,38)$. An advantage of evaluating transmission of $P$. infestans from seed tubers in a greenhouse over trials in the field is that moisture was regulated and that plants could be readily observed several times daily.

Sporulation and late-blight symptoms on shoots arising from infected tubers became evident within 24 to $48 \mathrm{~h}$ of the start of mist conditions in this study. The rapidity with which sporulation occurred suggests that mycelium of $P$. infestans was likely latently present in the aboveground stem tissue and produced sporangia and late-blight lesions upon exposure to the

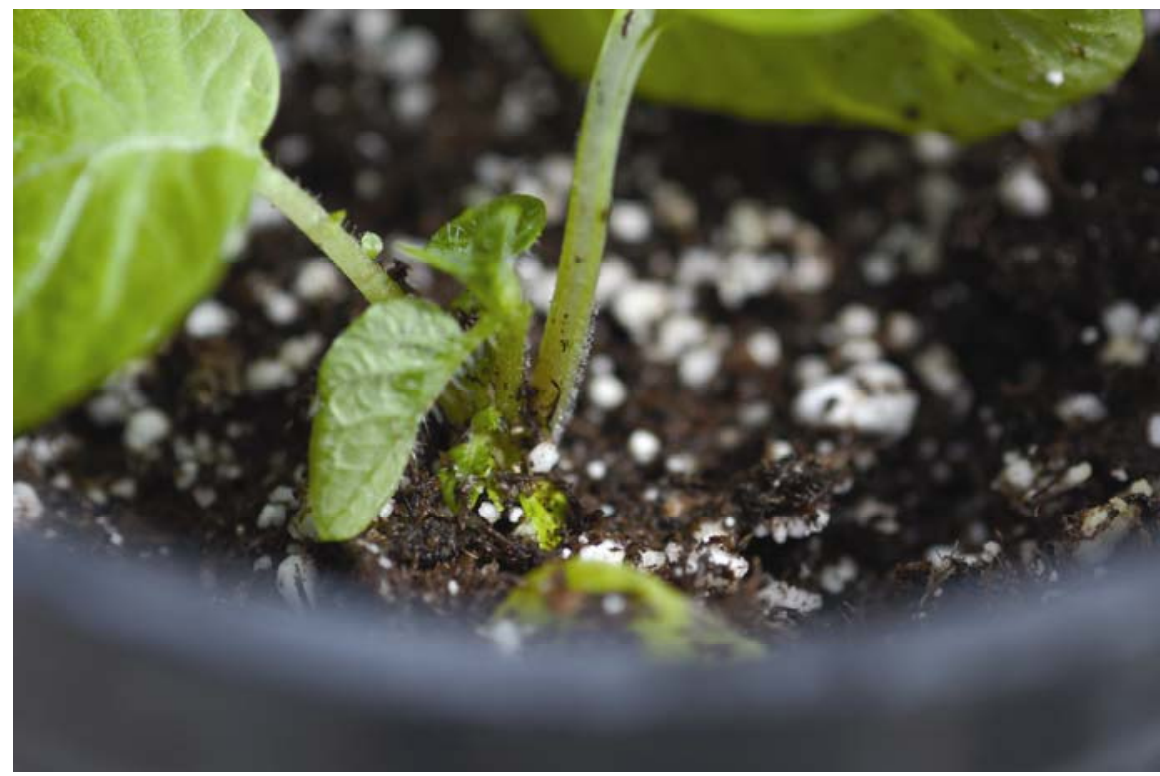

Fig. 1. Sporangia and sporangiophores of Phytophthora infestans showing "light sporulation" on the right side of the stem near the base. The photo was taken after the shoot emerged from an infected seed tuber and was exposed to a mist period for $24 \mathrm{~h}$ ( $45 \mathrm{~s}$ of mist every $15 \mathrm{~min}$ ). 
wet conditions. The latent period or time from inoculation to sporulation on young stems of Russet Burbank is generally 5 to 6 days for isolate BF05 (unpublished data), which is too long to congruously account for an infection being initiated from either sporangia or zoospores at the soil level of shoots during the wet period in this study. Latently infected shoots arising from infected tubers have been detected using PCR (4). Melhus reported that mycelium of $P$. infestans spreads most rapidly in the cortical tissues of the stem, where it travels more rapidly up than down, and that the pathogen progressed more rapidly in young than in old tissues (26).

Necrotic tissue was not observed on the belowground stems from the infected seed piece to the symptomatic aboveground stem tissues of seven examined stems in this study. Lesions on belowground stems arising from infected seed tubers have been previously observed and were expected in this study $(14,37,38)$. However, basal necrosis and necrosis beginning "some distance up the stem" (20) and plants with asymptomatic belowground stems and symptomatic aboveground stems have been previously observed on stems growing from planted infected seed pieces (7). Healthy-appearing belowground stem tissue between an infected seed piece and a lesion on an aboveground stem is shown in a figure in a recent article on late-blight management (33). Some researchers have not excavated belowground stems from soil of stems with aboveground symptoms to observe whether there was continuity of symptoms between the aboveground stems lesion and the parent tuber (14). Boyd (7) suggested that stems were infected near the soil surface by zoospores in the soil. Symptoms in this study appeared too rapidly after the beginning of the wet period to have originated from spores in the soil, given a 5- to 6-day incubation period. A possible explanation is that mycelium of $P$. infestans was latently present in the below- and aboveground stem but the belowground stem tissue was less susceptible to the development of necrosis. Development of necrotic tissue on belowground stem tissues would increase the likelihood of girdling and shoot death before sporulation on the aboveground stems, where sporangia could be dispersed in air currents and infect additional plants. Strains of the pathogen that do not rapidly girdle belowground stems from a latent infection would have a survival advantage over those that rapidly killed belowground stems. Additional work is needs to conclusively demonstrate the pathway of transmission from planted, infected seed tubers and to support a hypothesis that necrosis may be retarded on belowground, latently infected stems.

Sporangia produced on tubers during cutting and handling can potentially be- come airborne and be carried by air currents to cut tuber surfaces or tuber eyes within a handling and cutting facility or to plants and soil in a neighboring field, resulting in additional infections (25). Sporangia placed directly on tuber eyes were infective when tubers were planted. Cut tuber surfaces contain visible free water and are readily infected by sporangia directly deposited on them (unpublished data). Sporangia on tuber eyes may survive several days to weeks and later cause infection when the tubers are planted. Potato handling and cutting facilities are generally enclosed, blocking incoming solar radiation, which could also increase longevity of sporangia (36).

Infested loamy fine sand was infective when in contact with leaves during a wet period. Infection of foliage may also occur from splashing soil during wet periods. Efficiency of infection from contaminated soil appeared high, in that leaflets of all inoculated leaflets become infected in this study. Sporangia remained viable for 23 to 30 days in soil in the Columbia Basin in a previous study (31) and contaminated soil in the spring could serve as a source of initial infection for late-blight epidemics. This may explain field observations of initial lesions of late blight developing at the leaf tip touching the soil surface without other known infected plants nearby (7). Soil may become infested from sporangia produced on tubers or foliage in cull piles or on seed tubers during handling and cutting. Sporangia could then become airborne and be carried on air currents and deposited in a field (5). Sporangia can then survive in the soil and surface water in the field for 3 weeks $(24,30,31)$. Recent research in the Ecuadorian highlands where potato plants are cropped at various growth stages throughout the year demonstrated that sporangia of $P$. infestans can be deposited on field soil from infected foliage in adjacent fields and preemergently infect potato sprouts (23).

Inoculum originating from infected seed tubers in commercial fields can be especially devastating because of the potential earliness of the initial inoculum, the rapidity with which it can be produced, and the proximity of inoculum to the crop. A large number of seed tubers are planted in major potato production regions and only a few infected tubers are needed to initiate an epidemic (14,26,37,38). A few infected shoots arising from infected seed pieces in a commercial field is below the perception threshold and will not likely be noticed during the early stages of epidemics. Contemporary isolates of $P$. infestans, particularly the US-8 strain, are highly aggressive and rapidly rot tubers, limiting the availability of viable host tissue $(19,22,28)$. Tubers infected during handling and cutting just prior to planting may be more likely to produce viable shoots than those infected in the field near harvest because of less time for rot to develop before shoot emergence. In addition, transmission occurred from tubers to shoots when tubers were inoculated in the spring before planting but not when tubers were inoculated in the fall (12).

In conclusion, mist periods favored the expression of the pathogen in infected shoots emerging from infected seed tubers. Moist conditions favoring emergence of infected shoots would also favor sporulation and repeated infections in the field (13). Late-blight management strategies need to consider the effect of moisture on the development of infected shoots from seed tubers and an early and rapid increase of inoculum during epidemic development.

\section{ACKNOWLEDGMENTS}

Funding for this study was provided by the Washington State Potato Commission. I thank T. Cummings for technical assistance and D. Inglis and L. Porter for critical presubmission review of the manuscript.

\section{LITERATURE CITED}

1. Adler, N., Appel, R., and Habermeyer, J. 2001. Field experiments with seed treatment against late blight. PAV report no. 7, February 2001. Appl. Res. Arable Farm. Field Prod. Veg. 7:153-163.

2. Adler, N., Habermeyer, J., and Zinkernagel, V. 1999. PCR techniques used for detection of Phytophthora infestans latent infections in potato. PAV. No. 5, January 1999. Appl. Res. Arable Farm. Field Prod. Veg. 5:247-255.

3. Andrivon, D. 1995. Biology, ecology, and epidemiology of the potato late blight pathogen Phytophthora infestans in soil. Phytopathology 85:1053-1056.

4. Appel, R., Adler, N., and Habermeyer, J. 2001. A method for the artificial inoculation of potato tubers with Phytophthora infestans and polymerase chain reaction assay of latently infected sprouts and stems. J. Phytopathol. 149:287-292.

5. Aylor, D. E., Fry, W. E., Mayton, H., and Andrade-Piedra, J. L. 2001. Quantifying the rate of release and escape of Phytophthora infestans sporangia from a potato canopy. Phytopathology 91:1189-1196.

6. Boyd, A. E. W. 1974. Sources of potato late blight (Phytophthora infestans) in the east of Scotland. Plant Pathol. 23:30-36.

7. Boyd, A. E. W. 1980. Development of potato blight (Phytophthora infestans) after planting infected seed tubers. Ann. Appl. Biol. 95:301309.

8. Brooks, F. T. 1919. An account of some field observations on the development of potato blight. New Phytol. 18:187.

9. Davidse, L. C., Henken, J., van Dalen, A., Jespers, A. B. K., and Mantel, B. C. 1989. Nine years of practical experience with phenylamide resistance in Phytophthora infestans in the Netherlands. Neth. J. Plant Pathol. 95 (Suppl. 1):197-213.

10. De Bary, A. 1876. Researches into the nature of the potato-fungus-Phytophthora infestans. J. R. Agric. Soc 12:239-269.

11. Dowley, L. J., and O'Sullivan, E. 1991. Sporulation of Phytophthora infestans (Mont.) De Bary on the surface of diseased potatoes and tuber to tuber spread of infection during handling. Potato Res. 34:295-296.

12. Gigot, J. A., Gundersen, B., and Inglis, D. A. 2009. Colonization and sporulation of Phytophthora infestans on potato tubers under northwestern Washington conditions. Am. J. Potato Res. 86:1-14. 
13. Harrison, J. G. 1992. Effects of the aerial environment on late blight of potato foliage - a review. Plant Pathol. 41:384-416.

14. Hirst, J. M., and Stedman, O. J. 1960. The epidemiology of Phytophthora infestans II. The source of inoculum. Ann. Appl. Biol. 48:489-517.

15. Hussain, S., Lees, A. K., Duncan, J. M., and Cooke, D. E. L. 2007. Development of a species-specific and sensitive detection assay for Phytophthora infestans and its application for monitoring of inoculum in tubers and soil. Plant Pathol. 54:373-382.

16. Inglis, D. A., Powelson, M. L., and Dorrance, A. E. 1999. Effect of registered potato seed piece fungicides on tuber-borne Phytophthora infestans. Plant Dis. 83:229-234.

17. Johnson, D. A., Alldredge, J. R., Hamm, P. B., and Frazier, B. E. 2003. Aerial photography used for spatial pattern analysis of late blight infection in irrigated potato circles. Phytopathology 93:805-812.

18. Johnson, D. A., and Cummings, T. F. 2009. Latent infection of potato seed tubers by Phytophthora infestans during long term cold storage. Plant Dis. 93: 940-946.

19. Kadish, D., and Cohen, Y. 1992. Overseasoning of metalaxyl-sensitive and metalaxylresistant isolates of Phytophthora infestans in potato tubers. Phytopathology 82:887-889.

20. Keary, M. W. 1953. Delayed sporulation of Phytophthora infestans on infected potato shoots. Plant Pathol. 2:68-71.

21. Kirk, W. W. 2003. Thermal properties of overwintered piles of cull potatoes. Am. J. Potato Res. 80:145-149.

22. Kirk, W. W., Niemira, B. A., and Stein, J. M. 2001. Influence of storage temperature on rate of potato tuber tissue infection caused by Phytophthora infestans (Mont.) de Bary estimated by digital image analysis. Potato Res. 44:8696.

23. Kromann, P., Taipe, A., Andrade-Piedra, J. L., Munk, L., and Forbes, G. A. 2008. Preemergence infection of potato sprouts by Phytophthora infestans in the highland tropics of Ecuador. Plant Dis. 92:569-574.

24. Lacey, J. 1965. The infectivity of soils containing Phytophthora infestans. Ann. Appl. Biol. 56:363-380.

25. Lambert, D. H. Currier, A. I., and Olanya, M. O. 1998. Transmission of Phytophthora infestans in cut potato seed. Am. J. Potato Res. 75:257-263.

26. Melhus, I. E. 1915. Hibernation of Phytophthora infestans of the Irish potato. J. Agric. Res. 5:71-112.

27. Partipilo, H. M., Powelson, M. L., and Inglis, D. A. 2000. Seedborne Phytophthora infestans: Rate of transmission and effect on stand in five potato cultivars. Am. J. Potato Res. 77:415.

28. Pavek, M. J., and Thornton, R. E. 2005. A survey of stand establishment and in-row spacing uniformity in Washington potato fields. Am. J. Potato Res. 82:463-469.

29. Platt, H. W., Peters, R. D., Medina, M., and Arsenault, W. 1999. Impact of seed potatoes infected with Phytophthora infestans (US-1 or US-8 genotypes) on crop growth and disease risk. Am. J. Potato Res. 75:67-73.

30. Porter, L. D., and Johnson, D. A. 2004. Survival of Phytophthora infestans in surface water. Phytopathology 94:380-387.

31. Porter, L. D., and Johnson, D. A. 2007. Survival of sporangia of new clonal lineages of
Phytophthora infestans in soil under semiarid conditions. Plant Dis. 91:835-841.

32. Porter, L. D., Johnson, D. A., and Cummings, T. F. 2001. Development of Phytophthora infestans in potato tubers of nine clones in storage. (Abstr.) Phytopathology 91:S188.

33. Powelson, M., Ludy, R., Partipilo, H., Inglis, D., Gundersen, B., and Derie, M. 2002. Seedborne late blight of potatoes. APSnet Plant Health Progress research article. Http://www. planthealthprogress.org/current/management/ potatolate/top.htm.

34. Powelson, M. L., and Inglis, D. A. 1999. Foliar fungicides as protective seed piece treatments for management of late blight of potatoes. Plant Dis. 83:265-268.

35. Secor, G. A., and Johnson, S. B. 2008. Seed tuber health before and during planting. In: Potato Health Management, 2nd ed. D. A. Johnson, ed. American Phytopathological Society Press, St. Paul, MN

36. Sunseri, M. A., Johnson, D. A., and Dasgupta, N. 2002. Survival of detached sporangia of Phytophthora infestans exposed to ambient, relatively dry atmospheric conditions. Am. J. Potato Res. 79:443-450.

37. Vanderplank, J. E. 1963. Plant Diseases; Epidemics and Control. Academic Press, New York.

38. Van der Zaag, D. E., 1956. Overwintering en epidemiologie van Phytophtora infestans, tevens einige nieuwe bestrijdingsmoelijkheden. Tijdschr. Plantenziekten 62:89-156.

39. Zwankhuizen, M. J., Govers, F., and Zakoks, J. C. 1998. Development of potato late blight epidemics: Disease foci, disease gradients, and infection sources. Phytopathology 88:754-763. 